\title{
TIPS DAN TRIK MEMBANGUN RELATIONSHIP DAN QUERY DALAM DATABASE
}

\author{
Rizaldi $^{1}$, Dewi Anggraeni ${ }^{2}$, Arridha Zikra Syah ${ }^{3}$ \\ ${ }^{1,2,3}$ Sistem Informasi, STMIK Royal Kisaran
}

\begin{abstract}
Knowledge in building a database is one of the foundations for a person to build a computer-based application. In the database itself there are several parts that must be designed to build a database perfectly, ie tables, relationships, and queries. The students of SMK Swasta Nasional Kisaran is one of the objectives that is considered appropriate to understand and practice the science of the database, because the knowledge they can implement directly to their world of work will, of course, work related to the world of information technology, especially building a computer-based information system applications. The method used in learning to build this database, that is training, which in the training contains the study of database in theory, then practice directly using Microsoft Access 2007 application. The end result of this learning is the students of SMK Swasta Nasional Kisaran can know, understand, and practice directly on the computer using Microsoft Access 2007 applications, how tips and tricks to build tables, relationships, and queries, so that the database can be created perfectly.
\end{abstract}

Keywords: Database, Table, Relationship, Query

\begin{abstract}
Abstrak: Pengetahuan dalam membangun database merupakan salah satu dasar bagi seseorang untuk membangun sebuah aplikasi berbasis komputer. Dalam database itu sendiri terdapat beberapa bagian-bagian yang harus dirancang untuk terbangunnnya sebuah database dengan sempurna, yaitu tabel, relationship, dan query. Siswa SMK Swasta Nasional Kisaran salah satu sasaran yang dianggap tepat untuk memahami dan mempraktekan ilmu pengetahuan tentang database, karena pengetahuan tersebut dapat mereka implementasikan langsung pada dunia kerja mereka nantinya, tentunya pekerjaan yang berkaitan dengan dunia teknologi informasi, khususnya membangun sebuah aplikasi sistem informasi berbasis komputer. Metode yang digunakan dalam pembelajaran membangun sebuah database ini, yaitu pelatihan, yang di dalam pelatihan tersebut memuat tentang kajian database secara teori, kemudian praktek langsung menggunakan aplikasi Microsoft Access 2007. Hasil akhir dari pembelajaran ini adalah siswa SMK Swasta Nasional Kisaran dapat mengetahui, memahami, dan mempraktekkan langsung pada komputer menggunakan aplikasi Microsoft Access 2007, bagaimana tips dan trik membangun tabel, relationship, dan query, sehingga database dapat tercipta dengan sempurna.
\end{abstract}

Kata kunci: Database, Tabel, Relationship, Query

\section{PENDAHULUAN}

Peranan sistem informasi dalam organisasi, instansi pemerintah dan swasta sangat diperlukan untuk menunjang kinerja Sumber Daya Manusia (SDM).
Dengan adanya sistem informasi, pekerjaan yang berhubungan mulai dari pengolahan data sampai pada penyajian laporan, lebih efektif dan efesien jika dibandingkan dengan cara mencatat dan menulis dengan tangan. Sistem informasi 
Vol. 1, No. 2, Jul 2018, hlm. 45 - 50

ISSN 2614-7912 (cetak)

ISSN 2622-3813 (online)

Available online at http://jurnal.stmikroyal.ac.id/index.php/jurdimas

memiliki komponen-komponen yang saling mendukung untuk jalannya sistem sampai pada tujuan, yaitu informasi. Salah satu komponennya adalah database.

Database merupakan rumah atau tempat berkumpulnya tabel-tabel yang berisikan data. Pada saat sistem memproses penyajian informasi, database bereperan aktif memberikan data yang dibututhkan user. Membangun sebuah database yang profesional diperlukan keahlian dasar tentang database itu sendiri. Mulai dari menciptakan database sampai pembuatan tabel-tabel, relationship, dan query di dalamnya dibutuhkan pemahaman yang kuat baik secara teori maupun praktek

Siswa SMK Swasta Nasional Kisaran dianggap salah satu sasaran yang dianggap tepat untuk memahami dan mempraktekan ilmu pengetahuan tentang membangun sebuah database, karena pengetahuan tersebut dapat mereka implementasikan langsung pada dunia kerja mereka nantinya, tentunya pekerjaan yang berkaitan dengan dunia teknologi informasi, khususnya membangun sebuah aplikasi sistem informasi.

Hasil akhir dari pembelajaran ini adalah siswa SMK Swasta Nasional Kisaran dapat mengetahui, memahami, dan mempraktekkan langsung pada komputer, bagaimana tips dan trik membangun tabel, relationship, dan query, sehingga database dapat tercipta dengan sempurna.

\section{METODE}

Metode yang digunakan untuk mengimplementasikan kegiatan pengabdian kepada masyarakat adalah pelatihan yang meliputi penyuluhan, praktek, dan diskusi. Penyuluhan yang disampaikan berkaitan tentang pengertian, tujuan dan manfaat database, kemudian pengetahuan dan pemahaman tentang database tersebut diterapkan langsung (praktek) menggunakan aplikasi Microsoft Access 2007 melalui komputer. Evaluasi dari kegiatan ini dilakukan di akhir kegiatan, yaitu pada sesi tanya jawab dan diskusi.

\section{PEMBAHASAN}

Database merupakan wadah atau tempat berkumpulnya tabel-tabel yang memiliki atribut dan data. Tabel yang ada dalam database tersebut saling berhubungan satu sama lainnya, sehingga membentuk sebuah informasi yang dibutuhkan pengguna informasi tersebut. Penyajian informasi diproses menggunakan aplikasi atau program komputer, (Beranda Agency, 2015).

Microsoft Access merupakan program pengolahan database yang dapat mengolah berbagai jenis data serta membuat hasil akhir berupa laporan dengan tampilan yang lebih menarik. Tampilan jendela kerja Microsoft Access2013 tidak jauh berbeda dengan Microsoft Access sebelumnya, hanya ada beberapa fungsi yang dihilangkan karena kurang efektif dalam penggunaannya pada versi sebelumnya (Madcoms, 2015).

Penyimpanan data meliputi pekerjaan pengumpulan (filing), pencarian (searching), dan pemeliharaan (maintenance). Data disimpan dalam suatu tempat yang lazim dinamakan file. File dapat berbentuk map, ordner, disket, tape, harddisk, dan lain sebagainya. Sebelum disimpan, suatu data diberi kode menurut jenis kepentingannya. Pengaturan dilakukan sedemikian rupa sehingga mudah mencarinya. Pengkodean memegang peranan penting. Kode yang salah akan mengakibatkan data yang masuk ke dalam file juga salah yang selanjutnya akan mengakibatkan kesulitan dalam mencari data tersebut apabila diperlukan. Jadi, file diartikan sebagai 
Vol. 1, No. 2, Jul 2018, hlm. 45 - 50

ISSN 2614-7912 (cetak)

ISSN 2622-3813 (online)

Available online at http://jurnal.stmikroyal.ac.id/index.php/jurdimas

suatu susunan data yang terbentuk dari sejumlah catatan (record) yang berhubungan satu sama lain (sejenis) mengenai suatu bidang dalam suatu unit usaha (Tata Sutabri, 2012).

Tabel merupakan kumpulan dari beberapa record dan juga field. File merupakan record-record yang menggambarkan dari satu kesatuan data yang sejenis. Misalnya seperti file "Nama Siswa" berisikan data tentang semua nama siswa yang ada.

Record adalah kumpulan field yang sangat lengkap dan biasanya dihitung dalam satuan baris. Field yaitu tempat atau kolom yang terdapat dalam suatu tabel untuk mengisikan nama-nama (data) field yang akan di isikan.

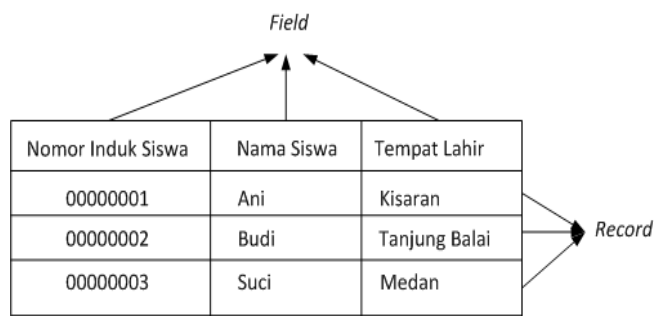

Gambar1. Contoh Field dan Record

Relationship merupakan sekumpulan tabel yang terhubung pada satu tabel inti, dimana tabel yang tempat berkumpul tabel-tabel lainnya tersebut (tabel inti) menjadi tempat membangun hubungan data antara tabel satu dengan tabel lainnya. Relationship menjadi dasar kenapa dikatakan bahwa database adalah kumpulan dari sejumlah tabel yang saling hubungan atau saling keterkaitan.

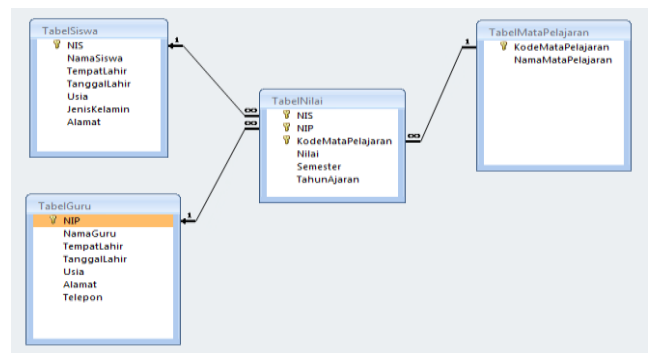

Gambar 2. Relationship
Dalam pembahasan menjelaskan dan menguraikan tentang peristilahan atau model (untuk jasa, keterampilan baru, dan rekayasa sosial-budaya), dimensi $\mathrm{dn}$ spesifiksi (untuk barang/peralatan) yang menjadi luaran atau focus utama kegiatan yang digunakan sebagai solusi yang diberikan kepada masyarakat, baik langsung maupun tidak langsung.

Query adalah semacam kemampuan untuk menampilkan suatu data dari database. Untuk mendapatkan data, query mengambilnya dari tabel-tabel yang ada di database, namun tabel tersebut tidak semua ditampilkan, hanya sesuai dengan yang kita inginkan (data apa yang ingin kita tampilkan). misal : data nilai siswa, maka nanti akan mengambil data dari tabel siswa, guru, mata pelajaran, dan nilai.

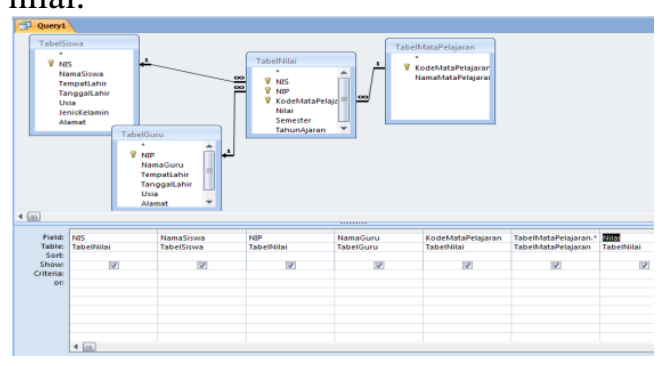

Gambar 3. Query Nilai Siswa

Salah satu kasus yang akan kita angkat untuk membangun relationship dan query di dalam sebuah database adalah "Nilai Siswa". Teori ini akan menuntun kita untuk memudahkan membangun relationship dan query nilai siswa dalam sebuah database. Software yang akan gunakan untuk membangun database adalah Microsoft Acces 2007, kalau tidak ada, boleh menggunakan Microsoft Access 2003 atau 2010. Silakan ikuti langkah ini dengan cara mempraktekan langsung pada komputer anda.

1. Sebelum merancang database, sebaiknya dibuat folder terlebih dahulu pada drive mana saja yang di 
Vol. 1, No. 2, Jul 2018, hlm. $45-50$

ISSN 2614-7912 (cetak)

ISSN 2622-3813 (online)

Available online at http://jurnal.stmikroyal.ac.id/index.php/jurdimas

inginkan (misal Drive $C$ atau $D$ ). Sekarang buat folder dengan nama "AplNilaiSiswa".

2. Silakan buka Microsoft Access 2007 dan klik Blank Database, lalu buat nama "DBNILAISISWA", dan simpan pada folder yang diuat sebelumnya, kemudian klik create. DBNILAISISWA merupakan nama database nilai siswa.

3. Selanjutnya klik view pada toolbar dan isilah table name dengan nama "TabelGuru", lalu klik $O k$.

4. Isi file name, data type, dan buat field sizenya sebagai berikut, NIP (text, 20), NamaGuru (text, 30), dan Alamat (text, 50), jadikan NIP primary key, lalu simpan / save.

5. Selanjutnya klik view pada toolbar dan isilah table name dengan nama “TabelMataPelajaran”, lalu klik $O k$.

6. Isi file name, data type, dan buat field sizenya sebagai berikut, KodeMataPelajaran (text, 5), NamaMataPelajaran (text, 30), jadikan KodeMataPelajaran primary key, lalu simpan / save.

7. Selanjutnya klik view pada toolbar dan isilah table name dengan nama "TabelNilai", lalu klik Ok.

8. Isi file name, data type, dan buat field sizenya sebagai berikut, NIS (text, 10), NIP (text, 20), KodeMataPelajaran (text, 5), nilai (Number, Integer), semester (text, 20), dan TahunAjaran (text, 20), jadikan NIS, NIP, dan KodeMataPelajaran primary key, lalu simpan / save.

9. Langkah berikutnya adalah membuat Relationship.

10. Klik database tools pada toolbar, lalu klik relationships.

11. Setelah muncul layar kosong, klik kanan layar tersebut dan klik show all. Maka tabel akan muncul semuanya.
12. Perhatikan pada tabel nilai. Pada tabel tersebut memiliki tiga primary key dan kita akan kaitkan dengan tabel yang lain, yang sama-sama memiliki primary key dan nama atribut yang sama.

13. Seret NIS dari tabel siswa pada NIS tabel nilai, centang semua yang ada pada edit relationship, lalu klik joint type, pilih yang nomor 3, lalu klik ok dan create.

14. Lakukan hal sama pada tabel guru dan tabel mata pelajaran.

15. Selanjutnya kita akan membuat query, Klik create pada toolbar dan klik query design.

16. Kemudian muncul kotak show table, silakan pilih tabel siswa dan klik add. Lakukan hal sama pada tabel guru, mata pelajaran, dan nilai.

17. Perhatikan kolom dan baris pada bagian bawan tabel-tabel tersebut, pada fiel pilihlah atribut, pada table pilihlah tabel. Mulai dari tabel nilai terlebih dahulu.

18. Catatan pada saat bertemu dengan atribut yang saling berhubungan dengan tabel lain, maka kita harus menyelesaikan/memilih data yang diinginkan pada tabel yang berelasi tersebut terlebih dahulu, kemudian lanjutkan pada tabel nilai sampai selesai.

Dibawah ini merupakan dokumentasi kegiatan pelatihan membangun database dengan tema Tips dan Trik Membangun Relationship dan Query Dalam Database.

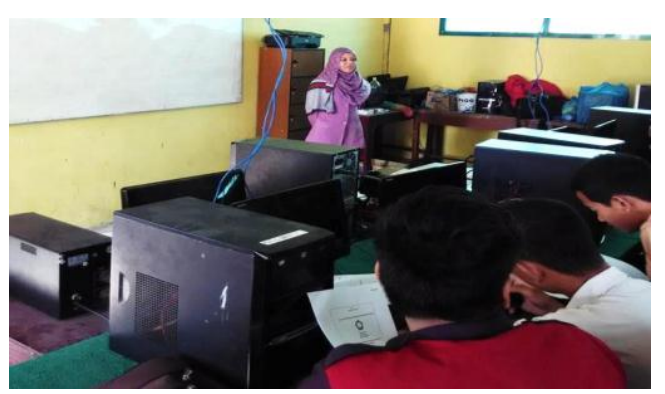

Gambar 4. Penyampaian Materi Oleh Nasumber 
Vol. 1, No. 2, Jul 2018, hlm. 45 - 50

ISSN 2614-7912 (cetak)

ISSN 2622-3813 (online)

Available online at http://jurnal.stmikroyal.ac.id/index.php/jurdimas

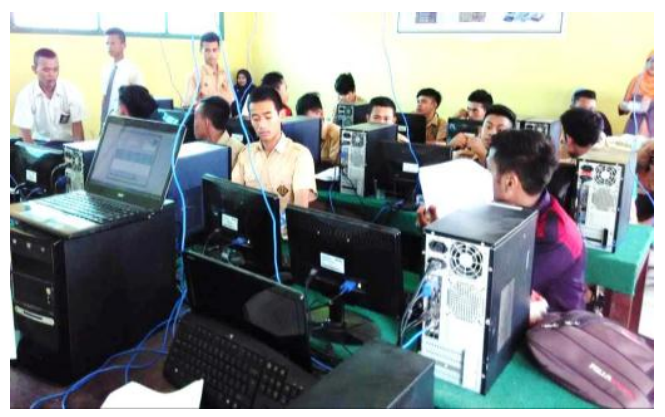

Gambar 5. Proses Belajar Mengajar Bagian 1

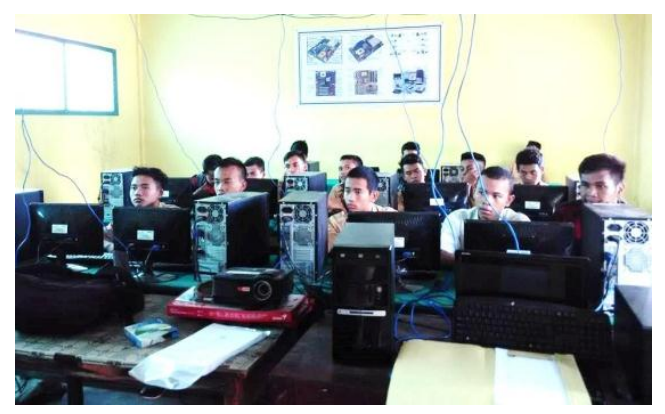

Gambar 6. Proses Belajar Mengajar Bagian 2

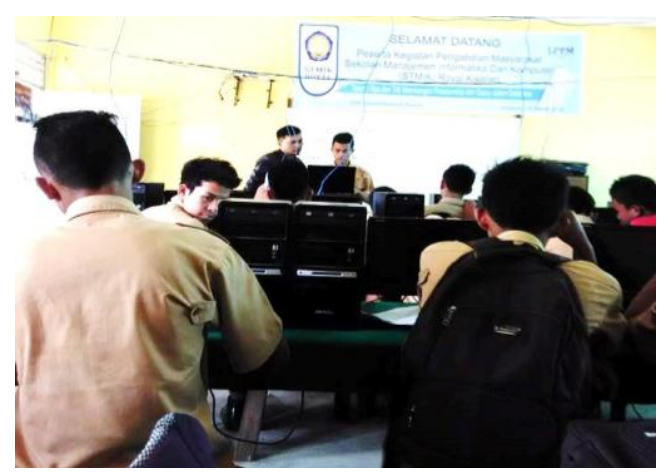

Gambar 7. Proses Praktikum



Gambar 8. Foto Bersama Peserta Kegiatan PKM Bagian 1

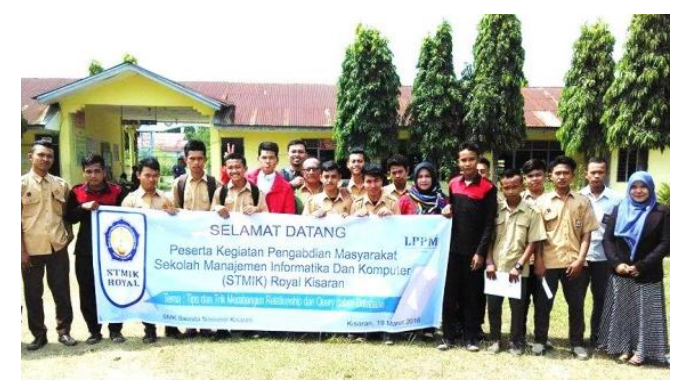

Gambar 9. Foto Bersama Peserta Kegiatan PKM Bagian 2

\section{SIMPULAN}

Kegiatan pengabdian kepada masyarakat yang dilakukan di SMK Swasta Nasional Kisaran sukses dilakukan sebagaimana yang diharapkan. Siswa-siswa sebagai peserta yang mengikuti kegiatan pelatihan membangun database mampu menguasai materi dan mengimplementasikan melalui aplikasi Microsoft Access 2007. Penguasaan database secara menyeluruh mulai dari membentuk tabel-tabel dalam database, merelasikan tabel-tabel tersebut satu dengan lainnnya (relationship) dan membangun query merupakan modal dasar bagi siswa-siswa SMK Swasta Nasional Kisaran untuk menjadi database administrator. Pengembangan selanjutnya peserta bisa melanjutkan pembelajaran tentang salah satu bahasa pemrograman, 
Vol. 1, No. 2, Jul 2018, hlm. 45 - 50

ISSN 2614-7912 (cetak)

ISSN 2622-3813 (online)

Available online at http://jurnal.stmikroyal.ac.id/index.php/jurdimas

misalnya PHP, JAVA, VBNet atau yang lainnya. Pembuatan aplikasi sistem informasi $90 \%$ akan berelasi dengan database, karena salah satu komponen sebuah sistem informasi adalah database yang berfungsi sebagai penampung data.

\section{UCAPAN TERIMA KASIH}

Kegiatan pengabdian kepada masyarakat ini tidak terlepas dari kerjasama dan bantuan materi, tenaga, dan fikiran dari berbagai pihak. Untuk itu, Tim pengabdian kepada masyarakat mengaturkan ucapan terima kasih kepada: 1) Bapak Anda Putra Lubis, SE., MMA, Ketua Yayasan Royal Teladan Asahan, sebagai penyandang dana, 2) Bapak Sangkot Mangapul Sitorus, Kepala Sekolah SMK Swasta Nasional Kisaran, sebagai mitra kegiatan pengabdian kepada masyarakat, 3) Tim pengabdian kepada masyarakat yang telah bekerjasama dengan baik, sehingga kegiatan dapat berjalan lancar dan sukses.

\section{DAFTAR PUSTAKA}

Abdul Kadir. 2014. Pengenalan Sistem Informasi Edisi Revisi. CV. Andi Offset. Yogyakarta

Andri Kristanto. 2007. Perancangan Sistem Informasi dan Aplikasinya.Gaya Media. Yogyakarta Beranda Agency. 2015. MS Access untuk Database Bisnis dan Perkantoran. PT. Elex Media Komputindo. Jakarta Fathansyah, 2015. Basis Data. Informatika Bandung. Bandung

Madcoms. 2015. Cepat dan Mudah Belajar Sendiri Microsoft Access 2013. CV. Andi Offset. Yogyakarta

Tata Sutabri. 2012. Konsep Sistem Informasi. CV. Andi Offset. Yogyakarta 